\title{
Strategy of BAZNAS and Laku Pandai For Collecting and Distributing Zakah in Indonesia
}

\author{
Kartika Andiani ${ }^{1}$, Didin Hafidhuddin ${ }^{2}$, Irfan Syauqi Beik ${ }^{3}$, Khalifah M Ali ${ }^{4}$
}

\begin{abstract}
As an important and potential instrument for national development, Zakah will continue to require development innovations. One of the innovation is through cooperation between BAZNAS and Laku Pandai which aims to achieve Zakah inclusion so that the collection and distribution of Zakah in Indonesia can increase. This study aims to analyze the strategic priorities for BAZNAS in running cooperation with Laku Pandai. This study used SWOT-ANP method with respondents as many as five expert respondents. The strategies derived from this research are the result of the formulation of a combination of SWOT factors. The main findings of this study indicate that the main priority of the overall strategy is strengthening the synergy of BAZNAS with the Laku Pandai of sharia banking.
\end{abstract}

Keywords: National Zakah Board, zakah collection, zakah distribution, zakah inclusion

\begin{abstract}
Abstrak. Sebagai instrumen penting dan sangat potensial bagi pembangunan nasional, Zakat akan terus membutubkan inovasi-inovasi pengembangan. Salah satunya melalui kerja sama antara BAZNAS dengan Laku Pandai yang bertujuan untuk mencapai inklusi Zakat, sehingga penghimpunan dan pendistribusian Zakat di Indonesia dapat meningkat. Penelitian ini bertujuan untuk menganalisis prioritas strategi bagi BAZNAS dalam menjalankan kerja sama dengan Laku Pandai. Penelitian ini menggunakan metode SWOT-ANP dengan responden sebanyak lima responden pakar. Strategi-strategi yang didapatkan dari penelitian ini merupakan hasil perumusan dari kombinasi faktor-faktor SWOT. Temuan utama dari penelitian ini menunjukkan bahwa prioritas utama dari keseluruhan strategi adalah penguatan sinergi BAZNAS dengan Laku Pandai perbankan syariah.
\end{abstract}

Kata kunci: badan amil zakat nasional, penghimpunan zakat, pendistribusian zakat, inklusi Zakat

\section{How to Cite:}

Andiani, K., Hafidhuddin, D., Beik, I. S., Ali, K. M. (2018). Strategy of BAZNAS and Laku Pandai for Collecting and Distributing Zakah in Indonesia. Al-Iqtishad: Jurnal Ilmu Ekonomi Syariah (Journal of Islamic Economics). Vol. 10 (2): 417 - 440. doi: http://dx.doi.org/10.15408/aiq.v10i2.6943.

\footnotetext{
Received: December 20, 2017; Revised: February 10, 2018; Accepted: March 4, 2018

${ }^{1,3,4}$ Bogor Agricultural University, Jalan Raya Dramaga, Bogor, Indonesia

${ }^{2}$ Ibn Khaldun University, Jalan KH Sholeh Iskandar Km 2, Bogor, Indonesia

E-mail: ${ }^{1}$ kartika.andiani@gmail.com, ${ }^{2}$ hafidhuddin@yahoo.com, ${ }^{3}$ qbeiktop@gmail.com, ${ }^{4}$ khalifahma@gmail.com

DOI: http://dx.doi.org/10.15408/aiq.v10i2.6943
} 


\section{Introduction}

Zakah inclusion is a program designed to publicise Zakah widely so that the Zakah activities can be accessed or done more easily by the community (OJK, 2017). The Zakah inclusion program basically is the efforts of BAZNAS (National Zakah Board) in strengthening the Zakah practice in national level. This program runs by the cooperation of BAZNAS with OJK (Financial Services Authority) to increase the literacy and Zakah financial inclusion in the community. The followup of this cooperation is presence of the synergy of BAZNAS with the Laku Pandai (Smart Act branchless banking service for financial inclusion) program that encourages the collection and distribution of Zakah through Laku Pandai agents that have been spread in the community.

Zakah is one of the philanthropy of Islam that has a strong role and impact, both for Zakah payers (muzaki) and Zakah beneficiaries (mustahik). It is an important instrument that can reduce the gap between the rich and the poor, alleviate the poverty, and has a contribution to the national economy. Therefore, Zakah is categorized as one of the most vital redistributive instruments. The AlQur'an clearly mentioned, in many verses, the responsibility of the rich to pay zakah (Abdullah and Haqqi, 2017). Zakah has become a very important Islamic fiscal tool to address the social justices (Al Arif, 2010; Al Haq and Wahab, 2017).

Several studies and surveys that have been done show the results of the calculation of the enormous potential of national Zakah. A survey by Public Interest Research and Advocacy Center (PIRAC) in 2008 estimated that the potential of Zakah in 2007 reached IDR 19.3 trillion. The calculations done by Firdaus et al. (2012) showed that the potential of national Zakah in 2011 reached IDR 217 trillion or about $3.4 \%$ of GDP 2010 by considering the potential of households' Zakah, medium and large industries Zakah, and State-Owned Enterprises (SOEs), as well as savings Zakah. Wibisono (2015) also calculated and found the potential of Zakah in 2010 that reached IDR 106.6 trillion (1.7\% of GDP 2010). With some adjustments, BAZNAS estimated that Indonesia’s potential of Zakah in 2015 was IDR 286 trillion or $2.4 \%$ of GDP 2015. As seen from the data published by BAZNAS annually, the realization of the collection and distribution of Zakah funds is still very far from its potential. In 2015, the total amount of ZIS funds collected was IDR 94.47 billion while the distributed amount was Rp26.5 billion, with the effectiveness of $26.91 \%$.

Hashem and El Sha'er (2015) in his study stated that Zakah can also encourage the achievement of an inclusive finance in a country by estimating the gap between the potential of collected Zakah as the source to eradicate the poverty and stabilize the income. By making estimates, it can be seen how much Zakah is 
required for state programs in reducing poverty to be effective. According to a study by Shirazi (2014), in 2009 Indonesia had a resource shortage of $2.83 \%$ of GDP for poverty eradication programs. Thus, according to the result of this study, it can be estimated that at least 3\% of GDP should be distributed optimally as Zakah so that the program can be run effectively. Muzaaki seems having different structure of zakah payment (Widarwati et al, 2017)

Now we see from the portrait of Indonesian muzaki. Canggih et al. (2017) try to estimate the number of Indonesians who are obliged to pay Zakah. In Table 1 , it can be seen that the average number of muzaki reaches about $39 \%$ of the total population of Indonesia. BAZNAS has also published data on the number of muzaki in Indonesia of 2012 to 2015. According to the provided data of the muzaki and compared to the estimation data by Canggih et al. (2017), it appears that the absorbed and recorded muzaki are still not maximized. Although the data is only the data from BAZNAS, but this can be used as a reference to photograph the performance of national treasure, because the database of mustahik and muzaki is not yet available nationally. There are several possibilities that occur based on this comparison, including indications that there are still many muzaki who have not accessed the OPZ to distribute their Zakah as well as the low awareness and knowledge of muzaki on the importance of paying Zakah.

Table 1. Estimation of Indonesian Muzaki

\begin{tabular}{clcr}
\hline Year & \multicolumn{1}{c}{$\begin{array}{c}\text { Population of } \\
\text { Indonesia }\end{array}$} & $\begin{array}{c}\text { Estimated Number of } \\
\text { Muzaki }\end{array}$ & $\begin{array}{c}\text { Number of } \\
\text { Muzaki }\end{array}$ \\
\hline 2006 & $229,263,980$ & $83,247,993$ & - \\
2007 & $232,296,830$ & $87,149,142$ & - \\
2008 & $235,360,765$ & $89,436,253$ & - \\
2009 & $238,465,165$ & $91,457,705$ & - \\
2010 & $241,613,126$ & $94,367,994$ & 1,220 \\
2011 & $244,808,254$ & $95,643,555$ & 36,888 \\
2012 & $248,037,853$ & $96,635,791$ & 30,176 \\
2013 & $251,268,276$ & $96,632,204$ & 59,903 \\
2014 & $254,454,778$ & $99,967,101$ & \\
2015 & $257,563,815$ & $100,133,823$ & \\
\hline
\end{tabular}

Source: Canggih et al. (2017); Puskas BAZNAS (2017) 
These issues indicate the importance of achieving and developing Zakah inclusion in Indonesia. BAZNAS together with OJK also establish a synergy to achieve these goals by organizing cooperation of collection and distribution of Zakah between BAZNAS with Laku Pandai. With the implementation of this cooperation, it is expected that Zakah inclusion can increase and the instrument of Zakah becomes the mainstream instrument in Indonesia for the national achievement of social and economic goals. This synergy is still relatively new to be applied in Indonesia because only a few months have passed since the launch of this program in April 2017. In the international world, other countries have not done this effort yet. Therefore, the implementation still needs to be followed by the identification of internal and external problems and strategies.

According to the explanation above, this research aims to formulate the priority of strategy for BAZNAS in its cooperation with Laku Pandai. To achieve these objectives, the SWOT-ANP method is used to prioritize each aspect of SWOT, and then an alternative strategy of the result of a combination of SWOT aspects is formulated. The novelty of this research is the absence of research that do strategy formulation of the cooperation between BAZNAS with Laku Pandai, because this cooperation was just launched in Indonesia.

In addition to this introduction, this article also comprises a review of the literature relevant to this study, delivered in the second section. The third section discusses the methods and data used in the analysis process, followed by the result and discussion in the fourth section. Finally, the fifth part is the conclusion from this study.

\section{Literature Review}

\section{Concepts of Zakah}

Etymologically, Zakah means developing (an-namaa), sanctifying (atthaharatu) and blessing (al-barakatu). In terminology, Zakah means the removal of some property in certain conditions to be given to a certain group (mustahik) with certain requirements (Hafidhuddin, 2002). The person who gives Zakah is called muzaki, while the person receiving the Zakah is called mustahik, which consists of eight groups (ashnaf), as Allah commands in verse 60 of At Taubah. Zakah is unique Islamic institution to reduce the poverty (Kasri, 2016).

Zakah is the third pillar in the principle of Islam. This obligatory worship not only brings reward and cleanses the body soul for the Muslims who fulfill it, but it also has a tremendous social and economic effect. Qardhawi (2011) mentions that Zakah is one part of social security in Islam, which is not known in the West, which 
includes the material and spiritual life. Zakah has a very important social role in building community welfare, poverty eradication, and economic empowerment of people. One of the functions of Zakah related to the importance of life development is as the main pillar in ensuring the fulfillment of basic needs for mustahik and be the instrument to create equity and economic justice (Beik and Arsyianti, 2016). Beik (2009) in his research shows that Zakah can reduce the number of poor families and reduce the poverty and income gap. The results of the analysis also proved that Zakah could reduce the severity of poverty. Zakah also contribute to country's economy. Choudhury and Harahap (2008) show the relationship between Zakah and the development of the country's economy. Zakah acts as an instrument of financial economic development. Zakah will give a significant multiplier effect to income in the economy (Al Arif, 2012)

Zakah also has a role to the financial inclusion that is now one of the attentions of the Indonesian government. There are at least four roles of Zakah on financial inclusion (Puskas BAZNAS, 2016b), those are: First, moderating social injustice; Second, generating a community-based economy; Third, promoting poverty reduction innovation; and Fourth, developing non-state fund for the prosperity of society. As stated by Ismail et al. (2016), that Islamic philanthropy such as Zakah, infaq, and alms affects people's ability to access formal finance through a transmission path. The mustahik's ability to has savings also become one of the components that are measured as points of mutahik's independence in the National Zakah Index (IZN) from BAZNAS (Puskas BAZNAS, 2016a). Muzaaki seems having different structure of zakah payment (Widarwati et al, 2017).

This shows that the ownership of savings account by mustahik is one of the benchmarks that the person has had the value of financial independence as a result of Zakah being distributed. If mustahik has been able to open and has a savings account in the formal financial sector, then it can be considered that the person has a fixed source of income and has been able to manage the finance to fulfill the primary needs and the family needs everyday.

\section{Branchless Banking and Laku Pandai Program}

Branchless banking is a form of financial services to community outside the bank branch office by utilizing information and communication technology (ICT) (Lyman et al., 2006). It lowers the cost of delivery, including costs both to bank for building and maintaining a delivery channel and to customers for accessing services (Ivatury and Mas, 2008). The principle of branchless banking implementation is the utilization of digital technology in attracting and accessing the wider community into financial services. The practice can be 
through collaboration with retail agents, microfinance institutions, mobile phone operators, and technology companies.

In Indonesia, branchless banking program was introduced in 2013. One of the programs is Laku Pandai. Laku Pandai, abbreviated from non-office financial services in the framework of inclusive finance, is a program that provides banking services and/or other financial services through cooperation with other parties (agents) and supported by the use of information technology (OJK, 2015). Laku Pandai is the implementation step of the branchless banking program to support the realization of Indonesia's inclusive finance. This inclusive finance is a national strategy to encourage economic growth that can be perceived by all societies through equal distribution of income, poverty eradication, and financial system stability.

The aim of Laku Pandai is to provide simple, easy-to-understand financial products that fulfill the needs of people who have not been able to reach current financial services (OJK, 2015). With this service, banking can more easily reach all segments of society. This also can be applied in the community so that their accessibility to financial services from banks and other financial institutions is not dependent on the existence of operational office. As it is said that branchless banking can lower the cost, Gant (2012) proves it through her research. The result shows that branchless banking through mobile banking has a significant positive effect on operational cost. This is because ICT can improve bank performace in two ways: reduce operational cost and facilitate transactions among customers within the same network (Ho and Mallick, 2006).

Laku Pandai is a form of branchless banking that use agents to reach the community. The agents act as an extension of the bank to its customers. Provided with supporting devices, such as mobile phones, computers, or EDC machines, agents can provide basic saving account (BSA), credit/ financing, also insurance services. Branchless banking through agents can significantly reduce set-up and delivery cost, offering cash-in/cash-out operations only or a broader range of financial services to customers who usually feel more comfortable at their local merchants than at traditional bank branches (Lozano and Mandrile, 2010). Aduba et al. (2013); Al Arif and Firmansyah (2018) show that branchless banking through bank agents has posititive effect to financial performance of bank. Number of agents and the number of transactions per agent also showed significant contribution to financial performance.

Reaching clients in rural areas will cost more. This can be a burden for banks, so that the presence of agents in the field can reduce the operational cost of banks. Also, agents in each area can encompass the community around them. Those points 
above also its contribution for banks and clients become the key why BAZNAS works together with Laku Pandai agents in collecting and distributing Zakah in Indonesia.

\section{Method}

This research used two types of data, primary and secondary data. Primary data that was obtained directly from the field by using interview and fulfilling questioner to research respondents. Research respondents was obtained from the institutions such as BAZNAZ, Puskas BAZNAS, BRI Syariah, BI, and DSN-MUI with total of five people. Criteria to determine the respondents were those who are experts who have deep understanding about research and issues of the research. Collected research data then will proceed with software of Super Decision and Microsoft Exel 2010. Secondary data was used as complementary and supportive primary data obtained from the sources such as OJK, BPS, BAZNAS, scientific journal, and others.

This research used Analytic Network Process (ANP). ANP is non parametric qualitative method to process decision making that gives general framework without making assumption (Ascarya, 2005). ANP is the result of developing Analytic Hierarchy Process (AHP) method and one of the method of multiple criteria decision making (MCDM), which has three steps: (1) model construction, (2) model quantification, and (3) synthesis and analysis (Figure 1). In step synthesis and analysis, analysis result of questioner is conducted to look for geometric mean and ratter-agreement values.

Geometric mean is average calculation type that shows certain value (Ascarya, 2005). The question of pairwise comparison from respondents will be combined so that it will from a consensus. Rater agreement is the measurement that shows conformity level of respondents toward an issue in a cluster. The tool used to measure is Kendall's Coefficient of concordance $(0<\mathrm{W} \leq 1)$. If $\mathrm{W}$ value is 1 , it shows that measurement or opinion of respondents have perfect adjustment. If $\mathrm{W}$ value is 0 , so there is incompatibility between the answers of respondents of the answers are vary (Ascarya, 2005).

ANP structure used in this research was SWOT system. SWOT is a simple technique to formulate the strategy and the policy for an organization or industry. The initial step done in SOWT analysis is forming SWOT matrix that contains list of strength, weakness, opportunity, and threat. SWOT matrix also shows interaction between internal and external aspects that will form alternative strategies (Table 2). 
Table 2. SWOT Matrix

\begin{tabular}{ccc}
\hline $\begin{array}{c}\text { Internal } \\
\text { External }\end{array}$ & Strength $(\mathbf{S})$ & Weakness $(\mathbf{W})$ \\
\hline Opportunity $(\mathrm{O})$ & $\begin{array}{c}\text { SO Strategy } \\
\text { Strategies that use strengths to } \\
\text { seize opportunities }\end{array}$ & $\begin{array}{c}\text { WO Strategy } \\
\text { Strategies that take advantage of } \\
\text { opportunities by overcoming weaknesses }\end{array}$ \\
Threat $(\mathrm{T})$ & $\begin{array}{c}\text { ST Strategy } \\
\text { Strategies that use strengths to } \\
\text { deal with threats }\end{array}$ & $\begin{array}{c}\text { WT Strategy } \\
\text { Strategies that minimize weakness and } \\
\text { avoid threats }\end{array}$ \\
\hline
\end{tabular}

Source: Wheelen dan Hunger (2008)

\section{Result and Discussion}

The cooperation between BAZNAS and Laku Pandai agents is an effort to strengthening Zakah instrument in Indonesia. This cooperation is conducted in Zakah association and distribution by BAZNAS that is mediated by Laku Pandai agents. With the support of government, the cooperation is considered as the effort to achieve Zakah inclusion. It is to strengthen Zakah role for social-economic life of the country and society. Zakah inclusion has to be achieved.

Based on the result of interview and SWOT-ANP steps that have been done, system that is formed is like in Figure 1. The system showed four analysis aspects as follow strength and weakness (internal) and opportunity and threat (external). Those aspects become base in formulating strategic addressed to implement the cooperation of BAZNAS and Laku Pandai aget to achieve Zakah inclusion in Indonesia.

\section{SWOT Analysis}

\section{Strengths}

BAZNAS Legality (S1)

BAZNAS is institution which is authorized in maintain Zakah nationally. BAZNAS does the function of planning, implementation, control, report, and responsibility toward collection, distribution, and empowerment of Zakah. It is based on Presidential Decree of Indonesia Number 8 in 2001 and arranged in Statue Number 23 in 2011 about Management of Zakah.

This legality becomes the the main strength for BAZNAS in doing strengthening efforts of national Zakah. In doing the duty, BAZNAS divides the tasks to BAZNAS local (including BAZNAS province, BAZNAS in regency/city, 
and also LAZ) that manage Zakah, infaq, and alms in each region. As official department of managing Zakah, effort and policy those are done by BAZNAS will become operational guideline for BAZNAS local and LAZNAS. The relations between BAZNAS and Laku Pandai agents are the position and status of BAZNAS as official and legal department in running the task, so this element becomes strength point of BAZNAS in strengthening Zakah efforts with various approach such as by cooperating with banking.

Figure 1. ANP Network

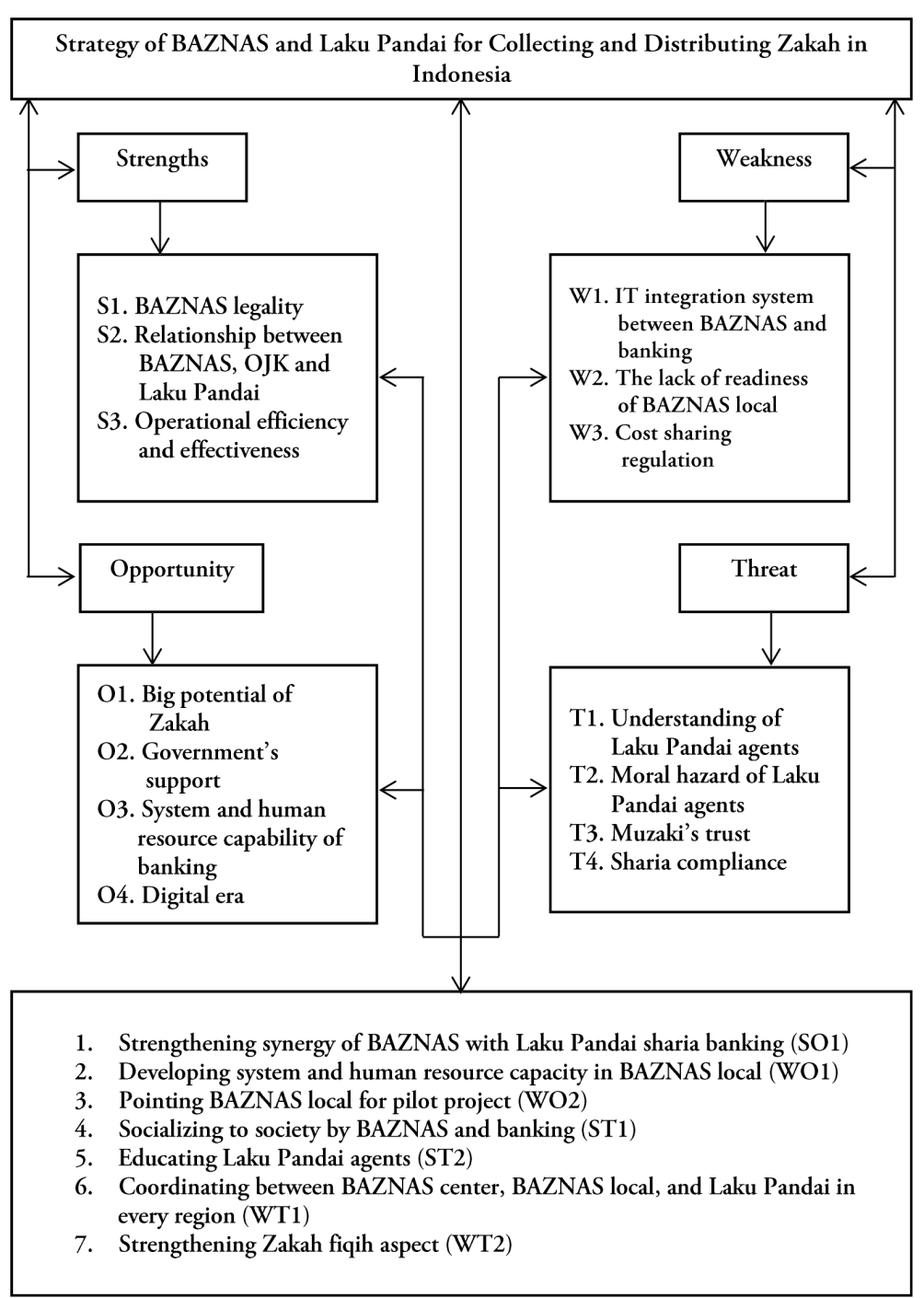


Relationship between BAZNAS, OJK, and Laku Pandai (S2)

The relation and cooperation of BAZNAS with external parties such as with banking will give easiness for BAZNAS and muzaki (Coryna \& Tanjung, 2015). The relation will run and it will be organized well if the relation and communication between the related parties run as the plan. BAZNAS cooperate with banking and OJK as banking and finance regulator that have strong and good relationship. Three parties has built communication and the same vision regarding to the purpose to achive finance inclusion and Zakah inclusion in Indonesia. Therefore, this element becomes one of BAZNAS strengths in implementing the cooperation. Kasri and Putri (2018) found that different type of zakah institutions indeed practices different fundraising strategies.

Operational efficiency and effectiveness (S3)

With the efforts of Zakah collection and distribution through Laku Pandai agents, thus, it can increase operational efficiency and and effectiveness of BAZNAS. BAZNAS utilizes agents in each region to help collection and distribution Zakah process from and to society. The aim of the cooperation is to achieve Zakah inclusion, that is enlarging society's knowledge and accessibility toward Zakah service so that it is expected that national Zakah acceptance will increase and the role of Zakah for the country will do the same. For the case of branchless banking, Purwati et al. (2014) show that more than $80 \%$ of respondents assume that by adopting branchless banking technology can save cost and time, also simplify services. Reducing operational cost also becomes one of the strengths which is influential in the implementation of branchless banking in Bank of Muamalat (Sarah, 2015).

Based on the data which was released by OJK, per September 2017 total of individual and department agents reached 428,852 agents in Indonesia. Even though the cooperation is finally based on banks that cooperate with BAZNAS, Laku Pandai agent is the party that does the program directly in collecting Zakah and distributing it.

\section{Weaknesses}

IT integration system between BAZNAS and banking (WI)

System integration is needed to ease and abbreviate data report mechanism of Zakah from Laku Pandai bank. With this system integration, Laku Pandai bank does not need to send acceptance report manually to BAZNAS because collected Zakah by agents can be recorded directly by IT BAZNAS system. Furthermore, BAZNAS can publish proof of Zakah deposit directly (BSZ) to muzaki. 
The lack of readiness of BAZNAS local (W2)

BAZNAS local readiness includes the readiness of IT system of human resource. It could become weakness that will inhibit cooperation implementation of BAZNAS with Laku Pandai in collecting and distributing Zakah in the region. BAZNAS local will become spearhead of the cooperation. It means, in the future BAZNAS local will directly cooperate with the agents of Laku Pandai in each region that can reach people in many and deeper regions. It is actually the real purpose from this cooperation, achieving Zakah inclusion, it means that accessibility of people toward Zakah payment and reception become easier.

BAZNAS local readiness can be considered become weakness of this cooperation if the elements in BAZNAS local such as human resource and IT system have been not ready in implementation. Coryna and Tanjung (2015) also say that the lack of readiness of BAZNAS local can inhibit communication process and evaluation of Zakah fund. Human resource of BAZNAS local have to understand well about operational of this cooperation. The support of IT system is needed to run this cooperation to advance level.

Cost sharing regulation (W3)

Cost sharing regulation is required to become guideline in deciding magnitude of the right and operating cost from each party in this cooperation. This regulation can include about amil's right that are accepted by BAZNAS or collected infaq in BAZNAS. Furthermore, bank will give rights of Laku Pandai agents with the terms of each bank.

\section{Opportunities}

Big potential of Zakah $(\mathrm{O} 1)$

Big potential of Zakah in Indonesia has proven through many researches, such as Firdaus et al. (2012) and Wibisono (2015). Big potential of Zakah can strengthen the important role as the effort of poverty alleviation and income distribution. It becomes element of opportunity for this cooperation. Big potential of Zakah in society needs innovative approaches to be able to excavate. BAZNAS and government understand Zakah potential that has been proofed through various calculations, so that cooperation becomes one of ways to increase realization of Zakah collection.

Government's support related to Zakah inclusion (O2)

Zakah inclusion is program that socializes Zakah including collecting, distributing, and empowering Zakah through Laku Pandai. This program is for 
increasing Zakah literacy and finance inclusion in society who also currently become the concern of the government. With OJK, BAZNAS launches this program through cooperation of BAZNAS and Laku Pandai in collecting and distributing national Zakah. As it is told by Sari et al. (2013) through her research, that government's support and intervention have the important role in managing Zakah. Government's support and caring toward the effort and cooperation of strengthening Zakah can ease implementation and increase positive impacts of this cooperation.

System and human resource capability of banking (O3)

Banking is finance department with availability of IT system and qualified human resource. Various services and operational in banking have utilized technology and active IT network. It becomes opportunity for cooperation between BAZNAS and Laku Pandai bank. By joining to utilize banking system and human resource, BAZNAS operational can run more effective and efficient.

Digital era (O4)

Entering $20^{\text {th }}$ century, globalization becomes the issue in every country including Indonesia. The life of human being is completed by using various digital technology. The stream of information and communication become fast and easy. ICT growth is currently giving a chance to provide faster and better services to most people (Santoso \& Ahmad, 2016). Innovative service that facilitating the ease should adopt technological sophistication through utilization for varying transactions (Supartoyo and Kasmiati, 2013). This fast digital era becomes good opportunity for development of Zakah management in Indonesia. Zakah management based on technology can work more professionally, trusted, transparent, and accountable.

\section{Threats}

Understanding participant bank of Laku Pandai related to mechanism of Zakah payment (T1)

The cooperation in collecting and distributing is conducted between BAZNAS and Laku Pandai agents. Laku Pandai agent is agency or individual that is registered in a bank to run the function and service of banking without office. The cooperation will increase offered services by agent to customer and society, it is reception of Zakah. It needs certain and depth understanding for bank and the agents so that they can socialize the service of Zakah payment to society in the operational region. 
Moral hazard of Laku Pandai agents (T2)

Deviation of function and work can happen anywhere and whoever, including the opportunity of Laku Pandai agents in doing moral hazard because of the lack of agent's understanding and awareness. Moral hazard can be prevented with good supervision by banking and enough debriefing from BAZNAS. Through a previous research, Purwati et al. (2014) show that $52 \%$ of respondents are concerned about fraud by agents and are reluctant to try new technology. This concern can occur from the lack of information received by respondents.

Muzaki's trust toward Laku Pandai agents (T3)

Trust element is crucial issue. Trust is the key for muzaki to will pay their Zakah through Zakah organization (OPZ). In this cooperation, the trust is required between muzaki toward Laku Pandai agents as service provider of Zakah payment.

Many previous research showed that trust of muzaki toward OPZ becomes one of problem in managing Zakah in Indonesia (Lessy, 2009; Ali, 2013; Coryna \& Tanjung, 2015). Laku Pandai agent has to have good knowledge and understanding about mechanism of Zakah payment and official identity as agents in a bank. With the growth of trust from muzaki, the role of Laku Pandai agents as one of payment point of Zakah can run effectively.

Sharia compliance (T4)

Sharia compliance has to be obtained in this cooperation because it is related to Zakah management. To obtain legitimate collection and distribution of Zakah in fiqih, so sharia aspects have to be compliant. This cooperation is conducted by BAZNAS and external parties, such as banking and Laku Pandai agents. In this case, Laku Pandai agent is extension of the hand BAZNAS in an attempt of collecting and distributing Zakah. Sharia compliance has to include agent status in this cooperation as amil or not as amil, cost sharing regulation, and more.

\section{The Result of ANP Analysis}

After ANP model and system have been formed, the next step is quantification process of priority value in every aspect and element. Priority value was showed by geometric mean value that was obtained from fulfilling questioner of pairwise comparison by respondents. 
Figure 2. SWOT Aspect

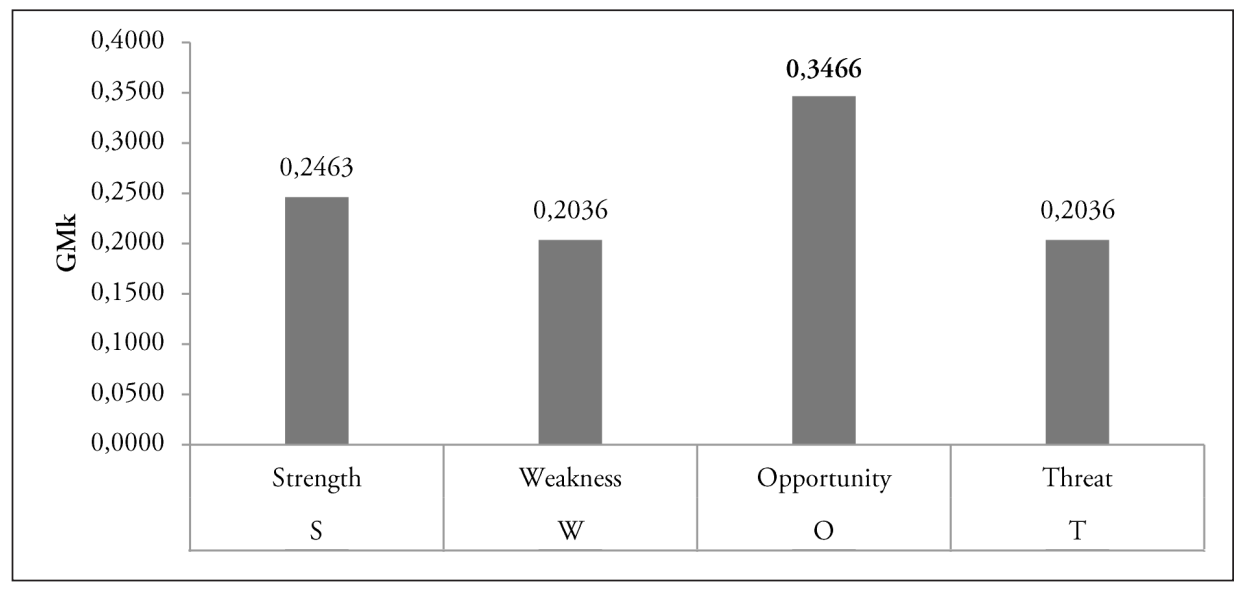

Figure 2 shows that between four SWOT aspects, opportunity aspect has the highest priority score of 0.3466 followed by strength aspect of 0.2463 . The calculation of rater agreement or respondents' value of the agreement obtains value $\mathrm{W}$ of 0.2295 . It means that $22.95 \%$ of respondents agree that opportunity aspect is the most priority aspect in implementing this cooperation. It means, opportunity aspect becomes the most influence aspect for BAZNAS in running the cooperation with Laku Pandai. Opportunity aspects consists of four elements. Big potential Zakah element with the support of government to achieve Zakah inclusion and the support from banking system and human resource become external strength for BAZNAS. This result is almost in line with Harni (2016) that shows opportunity aspect becomes second priority after strength aspect.

Based on experts who became respondents in this research, each aspect of strength until threat consist of four elements. In strength element, the good relationship between BAZNAS, banking, and OJK (0.3625) become the highest element. It shows that good communication and coordination between the parties became cooperation priority element to be launched (Figure 3). This cooperation was made by BAZNAS with external parties, Laku Pandai agents from bank. With good stream of communication and coordination between the parties, it will be easy for them to achieve mission and goal, Zakah financial inclusion in Indonesia.

Coordination is one of determinant sub-factors of project or cooperation. Good coordination is built between internal and external parties. Coordination is the tool to communicate with the parties related to the cooperation (Syah, 2004). 
Figure 3. Strength Aspect

\begin{tabular}{|c|c|c|c|}
\hline 0,4000 & & 0,3625 & \multirow{3}{*}{0,2911} \\
\hline 0,3500 & & & \\
\hline 0,3000 & & & \\
\hline 0,2500 & & & \\
\hline$\sum_{0=0}^{n} 0,2000$ & & & \\
\hline 0,1500 & & & \\
\hline 0,1000 & & & \\
\hline 0,0500 & & & \\
\hline & BAZNAS legality & $\begin{array}{l}\text { Relation between BAZNAS, } \\
\text { OJK, and Laku Pandai }\end{array}$ & $\begin{array}{c}\text { Operational efficiency and } \\
\text { effectiveness }\end{array}$ \\
\hline
\end{tabular}

Figure 4 shows weakness aspect, the priority is integrity of IT system between BAZNAS and banking (0.4579). To date, IT system between BAZNAS and banking are separated. Integration of IT system between both parties can ease report system and report of collection and distribution of Zakah fund so that it does not need to do manually. Based on the result of interview, Hamidiyah (2017) explains that Laku Pandai bank will send the report to BAZNAS, then BAZNAS will check deposit paper account of Laku Pandai agents, BAZNAS records every acceptance of Zakah to BAZNAS IT system and publishes Zakah deposit proof (BSZ) to muzaki.

Figure 4. Weakness Aspect

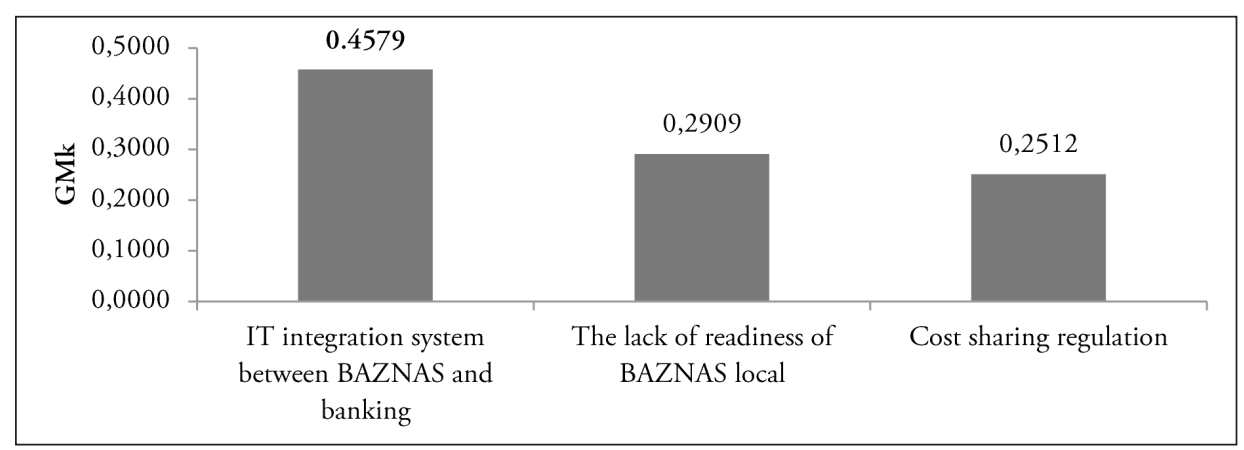

Figure 5 shows that big potential Zakah becomes main opportunity aspect, with the value of 0.2770 . In Ali (2013), the magnitude of national Zakah potential 
becomes second priority in opportunity aspect that is made for consideration in developing strategy of OPZ. Big Zakah potential is consequent from the big Muslim population in Indonesia that is amounted $87 \%$ and becomes the biggest population of Muslim in the world. As it has shown by the previous researches, Zakah potential in Indonesia is really big. There are many fund of Zakah in Indonesia that has not been collected by BAZNAS or LAZNAS because of many reasons such as lack of awareness and people's understanding, facilities, and access to pay Zakah (Sanrego and Rusydiana, 2010; Jaelani, 2015; Coryna and Tanjung, 2015).

Figure 5. Opportunity Aspect

\begin{tabular}{|c|c|c|c|c|}
\hline 0,3000 & 0,2770 & \multirow{2}{*}{0,2555} & \multirow[b]{2}{*}{0,2213} & \multirow{2}{*}{0,2462} \\
\hline 0,2500 & & & & \\
\hline 0,2000 & & & & \\
\hline$\sum_{j=0}^{\infty} 0,1500$ & & & & \\
\hline 0,1000 & & & & \\
\hline 0,0500 & & & & \\
\hline 0,0000 & Big potential of zakat & $\begin{array}{l}\text { Government's support } \\
\text { related to zakat } \\
\text { inclusion }\end{array}$ & $\begin{array}{l}\text { System and human } \\
\text { resource capability of } \\
\text { banking }\end{array}$ & Digital era \\
\hline
\end{tabular}

In threat aspect, the priority to be solved is muzaki's trust toward Laku Pandai agents with the value of 0.3274 (Figure 6). It is the same as previous researches that revealed one of external problem in managing national Zakah is the lack of muzaki's trust toward OPZ (Ali, 2013; Huda et al., 2013; Coryna \& Tanjung, 2015). Laku Pandai agents as extension of BAZNAS in collection and distribution Zakah program absolutely need the trust from muzaki so that muzaki have will to pay Zakah through agent in their environment.

Muzaki's trust becomes one of the success key in this cooperation. Through this research, Nugraha (2015) shows that muzaki's trust will encourage muzaki's commitment to pay Zakah to OPZ rather than pay directly to mustahik. The trust of customer (muzaki) to OPZ impacts to the availability to entrusted Zakah fund to OPZ. Then this trust will represent from the enhancement the collection of Zakah (Fadilah et al., 2012). 
Figure 6. Threat Aspect

\begin{tabular}{|c|c|c|c|c|c|}
\hline & \multirow[t]{2}{*}{ 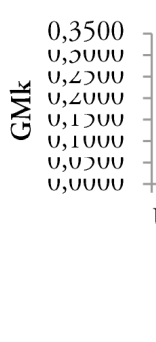 } & 0,2267 & 0,2352 & 0,3274 & 0,2108 \\
\hline & & $\begin{array}{c}\text { Understanding of Laku } \\
\text { Pandai agents related } \\
\text { to mechanism of zakat } \\
\text { payment }\end{array}$ & $\begin{array}{l}\text { Moral hazard of Laku } \\
\text { Pandai agents }\end{array}$ & $\begin{array}{l}\text { Muzaki's trust toward } \\
\text { Laku Pandai agents }\end{array}$ & Sharia compliance \\
\hline
\end{tabular}

\section{Strategy for BAZNAS and Laku Pandai}

An adoption of new technology or policy in society requires different adjustment and adoption models to maximize the process (Suharti et al., 2013). To minimize the weakness and resolve the threat by utilizing strength aspect and opportunity of BAZNAS and Laku Pandai, it needs conformity alternative strategies. Strategies are also needed to improve the implementation of this new cooperation. Based on SWOT matrix in Figure 9, there are seven alternatives of implementation that is formulated from combination of internal and external factors.

\section{SO Strategy}

SO strategy (Strength-Opportunity) is formulated strategy from the elements of strength and opportunity. This strategy utilizes internal strength to achieve external strength. In this opportunity, SO strategy for BAZNAS is strengthening strategy with Laku Pandai from sharia banking. Based on OJK data, sharia general bank (BUS) that have held Laku Pandai program until September 2017 are BRI Syariah and BTPN Syariah. Strengthening synergy strategy with Laku Pandai from sharia banking is based on BAZNAS legality (S1) and the good relation with OJK and banking (S2) that can encourage BAZNAS to achieve Zakah inclusion and big Zakah potential (O1) can also be collected. More Zakah fund that is collected, will be more muzaki's fund that is distributed productively or consummately for wealth of mustahik and society.

\section{WO strategy}

WO strategy (Weakness-Opportunity) is formulated strategy from elements of weakness and opportunity. WO strategy utilizes opportunity by resolving weakness. There are two alternative strategies, such as building system and human 
resource capacity in BAZNAS local and pointed BAZNAS local and Laku Pandai to implement pilot project of this cooperation. By doing implementation trial of BAZNAS local, it encourages BAZNAS local to get more ready in system and human resource and coordination with Laku Pandai agents in the region.

Table 3. Strategy based on SWOT Matrix

\begin{tabular}{|c|c|c|}
\hline $\begin{array}{l}\text { Internal } \\
\text { External }\end{array}$ & $\begin{array}{l}\text { Strengths }(\mathbf{S}) \\
1 \text { BAZNAS legality } \\
2 \text { Relationship between } \\
\text { BAZNAS, OJK, and Laku } \\
\text { Pandai } \\
3 \text { Operational efficiency and } \\
\text { effectiveness }\end{array}$ & $\begin{array}{l}\text { Weaknesses }(\mathrm{W}) \\
1 \text { IT integration system } \\
\text { between BAZNAS and } \\
\text { banking } \\
2 \text { The lack of readiness of } \\
\text { BAZNAS local } \\
3 \text { Cost sharing regulation }\end{array}$ \\
\hline $\begin{array}{l}\text { Opportunities }(\mathbf{O}) \\
1 \text { Big potential of Zakah } \\
2 \text { Government's support } \\
\text { related to Zakah inclusion } \\
3 \text { System and human resource } \\
\text { capability of banking } \\
4 \quad \text { Digital era }\end{array}$ & $\begin{array}{l}\text { SO Strategy } \\
1 \text { Strengthening synergy of } \\
\text { BAZNAS with Laku Pandai } \\
\text { from sharia banking }\end{array}$ & $\begin{array}{l}\text { WO Strategy } \\
1 \text { Developing system and } \\
\text { human resource capacity in } \\
\text { BAZNAS } \\
2 \text { Pointing BAZNAS local for } \\
\text { pilot project }\end{array}$ \\
\hline $\begin{array}{l}\text { Threats }(\mathbf{T}) \\
1 \text { Understanding Laku Pandai } \\
\text { agents } \\
2 \text { Moral hazard of Laku } \\
\text { Pandai agents } \\
3 \text { Muzaki's trust toward Laku } \\
\text { Pandai agents } \\
4 \text { Sharia compliance }\end{array}$ & $\begin{array}{l}\text { ST Strategy } \\
1 \text { Socializing to society by } \\
\text { BAZNAS and banking } \\
2 \text { Educating Laku Pandai } \\
\text { agents }\end{array}$ & $\begin{array}{l}\text { WT Strategy } \\
1 \text { Coordinating between } \\
\text { BAZNAS center, BAZNAS } \\
\text { local, and Laku Pandai in } \\
\text { every region } \\
2 \text { Strengthening Zakah fiqih } \\
\text { aspect }\end{array}$ \\
\hline
\end{tabular}

\section{ST Strategy}

ST strategy (Strength-Threat) is formulated strategy from elements of strength that is combined with threat elements. ST strategy uses strength to resolve threat that will occur. Combination result of S1 and S2 with T1, T2, and T3, there are two alternative strategies such as socialization to society by BAZNAS and banking and education Laku Pandai agents. The second alternative strategy is for avoiding and resolving moral hazard threat of Laku Pandai agents and distrust of muzaki toward the agents.

\section{WT Strategy}

WT strategy (Weakness-Threat) is formulated to minimize weakness to face the threat. There are two alternative strategies with Laku Pandai in region that is the 
result of W2 and T1 combination. The Second strategy is strengthening aspect of Zakah fiqih that is formulated from W3, T3, and T4.

\section{Strategy Priority}

Priority of whole strategy is strengthening synergy of BAZNAS with Laku Pandai from sharia banking (0.1819) with rater agreement value of 0.3257 (Figure 7). Synergy and cooperation is not only done by BAZNAS and conventional banking, but also with Laku Pandai from sharia banking. It is not only able to enlarge system of BAZNAS cooperation, but it also becomes opportunity for sharia banking and Laku Pandai program strengthen branding in society.

The second strategy is socialization in society by BAZNAS and banking (0.1688). it is really needed so that cooperation can work well because the target of the cooperation is the society. Without inclusive socialization, the goal of this cooperation will not be achieved. People have to know about the program and Laku Pandai agents near them. Because of this, Laku Pandai can be easier to introduce Zakah payment point service to society and ask them to pay Zakah through official agents.

\section{Figure 7. Strategy Priority}

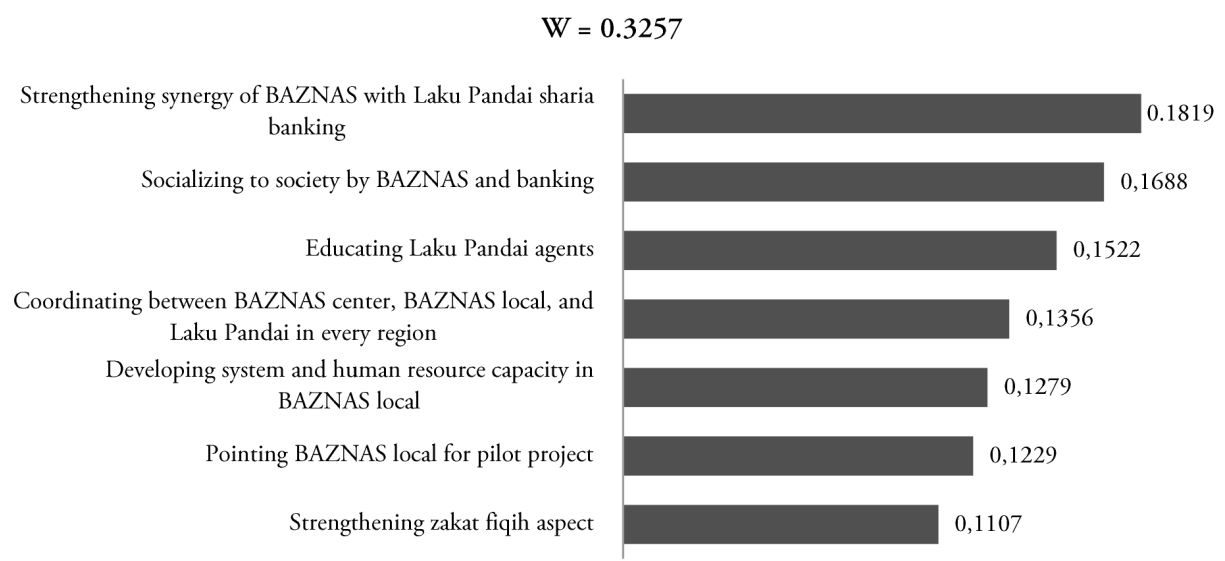

To be able to obtain understanding and solicitation to society, it is a must for Laku Pandai agents to have the kind of knowledge. Educating Laku Pandai agents becomes alternative strategy in third place with the value of 0.1522 . In her research, Sarah (2015) also shows that intensive training for agents becomes one 
of the strategies, in addition to facilitating agents to do promote and socialize to society. These can improve the role of branchless banking. Depth education about the mechanism is done by BAZNAS. This education and training can be done by conducting workshop between BAZNAS and Laku Pandai agents from related banking. It is not enough with workshop and education, evaluation is needed so that process of collection and distribution done by agents in field will continue to be measured and correspondent with determined standard.

\section{Conclusion}

The aim of the research is formulating strategy for BAZNAS in collection and distribution cooperation of Zakah with Laku Pandai agents. Formulated strategies are based on combination aspects of strength, weakness, opportunity, and threat that are faced by BAZNAS in this cooperation. To obtain the result priority, the used method is ANP method with SWOT matrix. This method will measure priority value and agreement level of respondents toward a priority result. Based on the result of the research, the most priority of strength aspect is element of good relationship of BAZNAS, OJK, and banking with priority level of 0.3466 . The most dominant weakness aspect is integration element of BAZNAS IT system and banking in priority level of 0.4579 . Priority opportunity aspect is big potential of Zakah with priority level of 0.2770 , whereas priority in threat aspect is muzaki's trust toward Laku Pandai agents with priority level of 0.3274 .

Strategies that are needed to be done by BAZNAS in the cooperation with Laku Pandai agents, such as strengthening synergy with Laku Pandai from sharia banking, socializing to society by BAZNAS and banking and educating Laku Pandai agents. Strengthening strategy with Laku Pandai from sharia banking become the main priority in whole strategy with the rater agreement value of 0.3257 .

Based on the result of the research, suggestion that can be given as follow: BAZNAS center can arrange integration system and IT system with banking system, especially to run the program of this cooperation. It absolutely will ease the report between both parties and to avoid the mistakes that will occur if it is done manually. Besides, BAZNAS center can choose BAZNAS local to run pilot project of the cooperation in the region. It is not only BAZNAS local as spearhead of this cooperation, it also can make BAZNAS to get ready to do trial of the cooperation with Laku Pandai agents in the region. The goal that is expected is BAZNAS local can become the example and evaluation for other BAZNAS local in different region that will do the same. The results of this study can be a reference for BAZNAS and Laku Pandai in formulating implementation strategies for this cooperation, so that the goals can be reached. 


\section{References}

Aduba, J., Kiragu, P., \& Ndwiga, J. M. (2013). The Relationship Between Agency Banking and Financial Performance of Commercial Banks in Kenya. Journal of Finance and Investment Analysis. Vol. 2(4): 97-117.

Al Arif, M. N. R. (2010). Efek Pengganda Zakat Serta Implikasinya Terhadap Program Pengentasan Kemiskinan (The Multiplief Effect of Zakah and The Implication to Poverty Alleviation Program). Jurnal Ekbisi. Vol. 5 (1): 42-49.

Al Arif, M. N. R. (2012). Efek Multiplier Zakat Terhadap Pendapatan di Provinsi DKI Jakarta (The Multiplier Effect of Zakah to Income in Jakarta). AlIqtishad: Jurnal Ilmu Ekonomi Syariah (Journal of Islamic Economics). Vol. 4 (1): 51-66.

Al Arif, M. N. R., \& Firmansyah. (2018). Laku Pandai's Program and Deposit Funds: Study at Bank of BRI Sharia. Jurnal Ekonomi. Vol. 23 (1): 1-9.

Al Haq, M. A., \& Wahab, N. B. A. (2017). Effective Zakah Distribution: Highlighting Few Issues and Gaps in Kedah, Malaysia. Al-Iqtishad: Jurnal Ilmu Ekonomi Syariah (Journal of Islamic Economics). Vol. 9 (2): 243-258. doi: https://doi.org/10.15408/aiq.v9i2.4002.

Ali, K. M. (2013). Masalah dan Solusi Zakah Nasional Perspektif Maqoshid Syariah Pendekatan AHP (Problems and Solutions of National Zakah through Maqoshid Sharia Perspective AHP Approach). (Unpublished Thesis). Depok: Universitas Indonesia.

Abdullah, R., \& Haqqi, A. R. A. (2017). Zakah for Asnaf Al-Gharimun in Brunei Darussalam: Concept and Practices. Al-Iqtishad: Jurnal Ilmu Ekonomi Syariah (Journal of Islamic Economics). Vol. 9 (2): 243-258. doi: https://doi. org/10.15408/aiq.v9i2.5092.

Ascarya. (2005). Analytic Network Process (ANP) Pendekatan Baru Studi Kualitatif (Analytic Network Process (ANP) A New Approach to Qualitative Studies). Proceding Seminar Intern Program Magister Akuntansi Fakultas Ekonomi. Jakarta.

Beik, I. S. (2009). Analisis peran Zakah Dalam Mengurangi Kemiskinan: Studi Kasus Dompet Dhuafa Republika (Analysis of The Role of Zakah in Reducing Poverty: Case study of Dompet Dhuafa Republika). Jurnal Pemikiran dan Gagasan 2. Retrieved from: https://www.researchgate.net/ profile/Irfan_Beik/publication/281207 037_Analisis_Peran_Zakah_dalam_ Mengurangi_Kemiskinan_Studi_Kasus_Dompet_Dhuafa_Republika/ links/55db325508aed6a199ac553e.pdf

Beik, I. S., \& Arsyianti, L. D. (2016). Ekonomi Pembangunan Syariah (Sharia Economics Development). Jakarta: Rajawali Pers. 
Canggih, C., Fikriyah, K., \& Yasin, A. (2017). Inklusi Pembayaran Zakah di Indonesia (Inclusion of Zakah payments in Indonesia). Jurnal Ekonomi dan Bisnis Islam. Vol. 3(1): 1-11.

Coryna, I. A., \& Tanjung, H. (2015). Formulasi Strategi Penghimpunan Zakah oleh Badan Amil Zakah Nasional (BAZNAS) (The Formulation of Zakah Collection Strategy by National Zakah Board (BAZNAS)). Journal of Al Muzara'ah. Vol. 3(2): 154-179.

Choudhury, M. A., \& Harahap, S. S. (2008). Interrelationship Between Zakah, Islamic Bank, and The Economy: A Theoretical Exploration. Managerial Finance. Vol. 34(9): 610-617.

Fadilah, S., Nurlaeli., Lestari, R., \& Helliana. (2012). Membangun kepercayaan konsumen: Faktor penting pada Lembaga Amil Zakat seluruh Indonesia (Building consumer trust: An important factor in Amil Zakah Institution throughout Indonesia). Prosiding SnaPP 2012: Sosial, Ekonomi, dan Humaniora. Vol. 3(1): 127-137.

Firdaus, M., Beik, I. S., Irawan, T., \& Juanda, B. (2012). Economic Estimation and Determinations of Zakah Potential in Indonesia. IRTI Working Paper Series \#1433-07. Jeddah: IRTI-IDB

Gant, A. (2012). Effects of Mobile Banking on Microfinance Institution Performance in Kenya. (Unpublished Thesis). Washington DC: Georgetown University.

Hafidhuddin, D. (2002). Zakat dalam Perekonomian Modern (Zakah in The Modern Economy). Jakarta: Gema Insani Press.

Harni, M.S. (2016). Strategi Pengembangan Bisnis Pengolahan Pala di UD. Putra Mandiri Kecamatan Tamansari Kabupaten Bogor (Strategy of Business Development of Nutmeg at UD. Putra Mandiri Tamansari District Bogor Regency). (Unpublished Thesis). Bogor: Bogor Agricultural University.

Hashem, E.A., S. El Shaer. (2015). Can Zakah help to enhance financial inclusion? Case study Egypt. International Journal of Education and Research. Vol. 3(3): 413-432.

Ho, S.J., S. K. Mallick. (2006). The Impact of Information Technology on The Banking Industry: Theory and Empirics. United Kingdom (UK): Queen Mary University of London.

Huda, N., Anggraini, D., Ali, K. M., Rini, N., \& Mardoni, Y. (2013). Komparasi AHP dan ANP penentuan solusi pengelolaan Zakah (Kasus DKI dan Sulsel) (Comparation between AHP and ANP in determination of Zakah management solution (Case of DKI and South Sulawesi). Journal of Ekuitas. Vol. 17(3): 357-375. 
Ibrahim, P. (2006). Economic Role of Zakah in Reducing Income Inequality and Poverty in Selangor. (Unpublished Dissertation). Selangor: Universiti Putra Malaysia.

Ismail, A.G., Zaenal, M. H., \& Taufiq, U. (2016). Can Islamic philantrophy increase financial inclusion?. IRTI Working Paper \#1437-02. Jeddah: IRTI IDB

Jaelani, A. (2015). Zakah Management in Indonesia and Brunei Darussalam. Cirebon: Nurjati Press.

Kasri, R. A. (2016). Effectiveness of Zakah Targeting in Alleviating Poverty in Indonesia. Al-Iqtishad: Jurnal Ilmu Ekonomi Syariah (Journal of Islamic Economics).Vol. 8 (2): 169-186. doi: https://doi.org/10.15408/aiq.v8i2.3005.

Kasri, R. A., \& Putri, N. I. S. (2018). Fundraising Strategies to Optimize Zakah Potential in Indonesia: An Exploratory Qualitative Study. Al-Iqtishad: Jurnal Ilmu Ekonomi Syariah (Journal of Islamic Economics). Vol. 10 (1): 1-24. doi: https://doi.org/10.15408/aiq.v10i1.6191.

Lessy, Z. (2009). Zakah (alms - giving) Management in Indonesia. LaRiba Jurnal Ekonomi Islam. Vol. 3(1): 106-119.

Lozano, D. M., \& Mandrile, M. (2010). A New Agent Model for Branchless Banking in Colombia. International Development Law Organization. pp. 1-20.

Lyman, T. R., Ivatury, G., \& Staschen, S. (2006). Use of Agents in Branchless Banking for The Poor: Rewards, Risks, and Regulations. CGAP Focus Note No. 38.

Nugraha, E. (2015). Pengaruh Akuntabilitas, Transparansi, dan Kualitas Pelayanan Lembaga Pengelola Zakah terhadap Kepercayaan Muzaki dan Pengaruh Kepercayaan Muzaki terhadap Komitmen Muzaki (The Impact of Accountability, Transparency, and Service Quality of Zakah Management Institution to Muzaki's Trust and Muzaki's Trust Effect on Muzaki's Commitment). (Unpublished Thesis). Lampung: University of Lampung.

Purwati, Y., Franksiska, R., \& Nugroho, P. I. (2014) Strategi Peningkatan Kemampuan Adopsi Teknologi Branchless Banking Untuk Memperluas Inklusi Keuangan di Masyarakat Pedesaan (Strategy to Increase the Capability of Adoption of Branchless Banking Technology to Expand Financial Inclusion in Rural Communities). National Seminar: Research Methods and Organizational Studies: 201-211.

Pusat Kajian Strategis BAZNAS (Puskas BAZNAS). (2016a). Indeks Zakah Nasional (National Zakah Index). Jakarta: Puskas BAZNAS.

Pusat Kajian Strategis BAZNAS (Puskas BAZNAS). (2016b). Indonesia Zakah Outlook 2017. Jakarta: Puskas BAZNAS.440 
Pusat Kajian Strategis BAZNAS (Puskas BAZNAS). (2017). Indonesia Zakah Outlook 2018. Jakarta: Puskas BAZNAS.

Qardhawi, Y. (2011). Hukum Zakat (Law of Zakah). Bogor: Pustaka Litera Antarnusa. Sanrego, Y. D., \& Rusydiana, A. S. (2010). Analisis Problem PerZakatan di Indonesia Dengan Pendekatan Metode Analytic Network Process (ANP) (Analysis of Zakah Problems in Indonesia with Analytic Network Process (ANP) method approach). Working Paper. Bogor: LP2M STEI TAZKIA.

Santoso, B., \& Ahmad, K. (2016). Islamic Microfinance Branchless Banking Model in Indonesia. Intelectual Discourse. Special Issue: 409-433.

Sarah, H. (2015). Dampak Branchless Banking terhadap Kinerja Keuangan PT Bank Mualamat Indonesia Tbk (Impact of branchless banking on financial performance of PT Muamalat Indonesia Tbk). Journal of Al-Muzara'ah. Vol. 3(2): 136-157.

Sari, M. D., Bahari, Z., \& Hamat, Z. (2013). Review on Indonesia Zakah Management and Obstacles. Social Science. Vol. 2(2): 76-89.

Shirazi, N. S. (2014). Integrating Zakah and waqf into the poverty reduction strategy of the IDB member countries. Islamic Economic Studies. Vol. 22(1): 79-108.

Suharti, L., L. Soegiono, Y. Purwati. (2013). Technology innovation adoption model among SME Tempe producer (A study on Tempe produces in Center Java Indonesia). International Journal of Business and Management Invention. Vol. 3(2): 5-14.

Supartoyo, Y. H., \& Kasmiati. (2013). Branchless Banking Mewujudkan Keuangan Inklusif Sebagai Alternatif Solusi Inovatif Menanggulangi Kemiskinan: Review dan Rekomendasi (Branchless Banking Actualizies Inclusive Finance as an Alternative Innovative Solution to Alleviate Poverty: Review and Recommendation). Working Paper. Graduate School Bogor Agricultural University.

Syah, M.S. (2004). Manajemen Proyek: Kiat Sukses Mengelola Proyek (Project Management: Tips for Managing Project Success). Jakarta: Gramedia Pustaka Utama.

Wibisono, Y. (2015). Mengelola Zakat Indonesia: Diskursus Pengelolaan Zakat Indonesia dari Rezim UU No. 38 Tahun 1999 ke Rezim UU No. 23 Tahun 2011 (Managing Zakah Indonesia: Discussion of Indonesia Zakah Management from Regime of Law No. 38 of 1999 to Regime of Law No. 23 of 2011). Jakarta: Prenada Media.

Widarwati, E., Afif, N. C., \& Zazim, M. (2017). Strategi Approach for Optimizing of Zakah Institution Performance: Customer Relationship Management. AlIqtishad: Jurnal Ilmu Ekonomi Syariah (Journal of Islamic Economics). Vol. 9 (1): 81-94. doi: https://doi/org/10.15408/aiq.v9i1.4010.

Wheelen, T. L., \& Hunger, J. D. (2008). Strategic Management and Business Policy. New Jersey: Pearson Education. 